\title{
ANÁLISIS
}

\section{ENTENDER LOS BANCOS DE IMÁGENES}

\section{Lluís Codina}

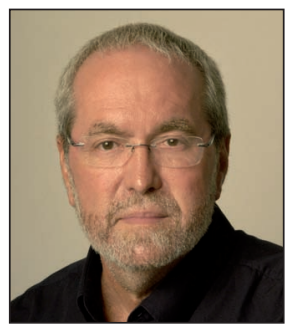

Lluís Codina es profesor titular del Departamento de Comunicación de la Universidad Pompeu Fabra (UPF) y director de la Unidad de Soporte a la Calidad y a la Innovación Docente (Usquid) de la Facultad de Comunicación. Imparte docencia en los Estudios de Periodismo y de Comunicación Audiovisual. Participa en masters oficiales y en programas de doctorado del Departamento de Comunicación. Coordina el Grupo de Investigación en Documentación Digital y Comunicación Interactiva y forma parte del Grupo de Investigación en Periodismo, ambos grupos reconocidos de la UPF y el último por la Generalitat de Catalunya. Es fundador y codirector del primer máster que se imparte íntegramente en la Web sobre Documentación Digital, del Anuario Hipertext.net y coeditor del weblog sobre documentación digital Servicio de Alerta.

Departament de Comunicació, Universitat Pompeu Fabra Roc Boronat, 138, desp. 53.804 - 08018 Barcelona lluis.codina@upf.edu http://www.lluiscodina.com

\section{Resumen}

Caracterización del sector de los bancos de imagen en el ecosistema de la información. Se describen sus principales características en relación con tres ejes dicotómicos principales: la fotografía de encargo vs. la fotografía de stock; el sector editorial vs. el sector creativo; las licencias con derechos reservados vs las licencias libres de derechos. Finalmente, se presenta una breve revisión de los repositorios abiertos y las imágenes con licencias Creative Commons.

\section{Palabras clave}

Ecosistema de la información, Bancos de imágenes, Tipos de licencias, Sistemas comerciales, Repositorios abiertos.

\section{Title: Understanding the stock photography sector}

\begin{abstract}
Characterization of the stock photography sector in the context of the information ecosystem. Its main features are described in relation to three key axes of dichotomy: contracted vs. stock photography; the editorial vs creative sector; and copyright- protected vs. royalty-free licenses. Finally, a brief review of open repositories and Creative Commons licensed images is offered.
\end{abstract}

\section{Keywords}

Information ecosystem, Stock photography, Image licenses, Commercial systems, Open repositories.

Codina, Lluís. “Entender los bancos de imágenes". El profesional de la información, 2011, julio-agosto, v. 20, n. 4, pp. 417-423.

http://dx.doi.org/10.3145/epi.2011.jul.08

\section{Introducción: el ecosistema de la información}

El conjunto de los sistemas de información, sus interacciones, su diversidad y especialización en auténticos nichos, forman lo más parecido a un ecosistema. Las diferentes especies se identifican con distintos sistemas: buscadores, bases de datos, opac, etc., y sus interacciones son cada vez más ricas gracias a la web 2.0 y a las tecnologías de la web semántica.
Los seres humanos naturalmente formamos parte del sistema, bien como administradores y desarrolladores del mismo, o bien como productores y consumidores de la información.

En lugar de materia y energía, en este ecosistema circula información, y sin duda podemos afirmar que una especie relativamente nueva se ha unido, y con mucho éxito, al mismo: los bancos de imagen. 
En lo que sigue, para poder entender los bancos de imagen, adoptaremos como marco de referencia el mundo de la comunicación en sentido amplio. Es decir, discutiremos sus características en el contexto de su utilización con fines de comunicación. Por ejemplo, en una publicación periódica, un sitio web, una campaña de publicidad o una producción audiovisual (más adelante hablaremos un poco más sobre la segmentación del mercado de los bancos de imagen).

En este sentido, lo cierto es que siempre que hablamos de temas relacionados con la información, se nos impone la idea de motores de búsqueda como Google. Un profano en la materia podría preguntarse para qué necesitamos una nueva especie (los bancos de imágenes) si buscadores como Google o Bing hace tiempo que son capaces de localizar, indizar e incorporar imágenes a sus resultados y además con notable éxito y aparente eficiencia.

Sin embargo, cabe señalar que los motores de búsqueda no son una solución si vamos más allá de lo lúdico o de un uso meramente personal o privado. Y ello es así por diversas razones, aunque destaca en primer lugar el binomio formado por la propiedad intelectual y los derechos de imagen.

Se dice que los motores realizan una búsqueda agnóstica. Lo que significa esto es lo siguiente: cuando un motor de búsqueda devuelve un serie de imágenes en respuesta a una pregunta, lo hace ignorando de forma expresa los posibles derechos de propiedad de esas imágenes. Por lo tanto, a la hipotética pregunta que podríamos hacerle a un buscador: “¿qué derechos reservados tienen estas imágenes"?, la respuesta virtual del buscador sería: "no lo sé, y no tengo modo de saberlo con seguridad". Si hiciéramos la pregunta pertinente en el caso de que aparezcan personas: "¿han dado su permiso las personas de la imagen para que se pueda reproducir la fotografía"? la respuesta del buscador volvería a ser la misma: "no lo sé, etc.".

En realidad este primer problema ya invalidaría el uso de motores de búsqueda en el contexto que hemos establecido, pero (en un orden no significativo) podemos citar otros tres: la escasa calidad de las imágenes, la imposibilidad material de acceder a imágenes históricas o simplemente de cierta antigüedad y, por último, pero no menos importante, la imposibilidad de efectuar búsquedas con los criterios que suelen necesitar los usuarios, por ejemplo, que la imagen sea de una orientación determinada (p. e. vertical) o que en

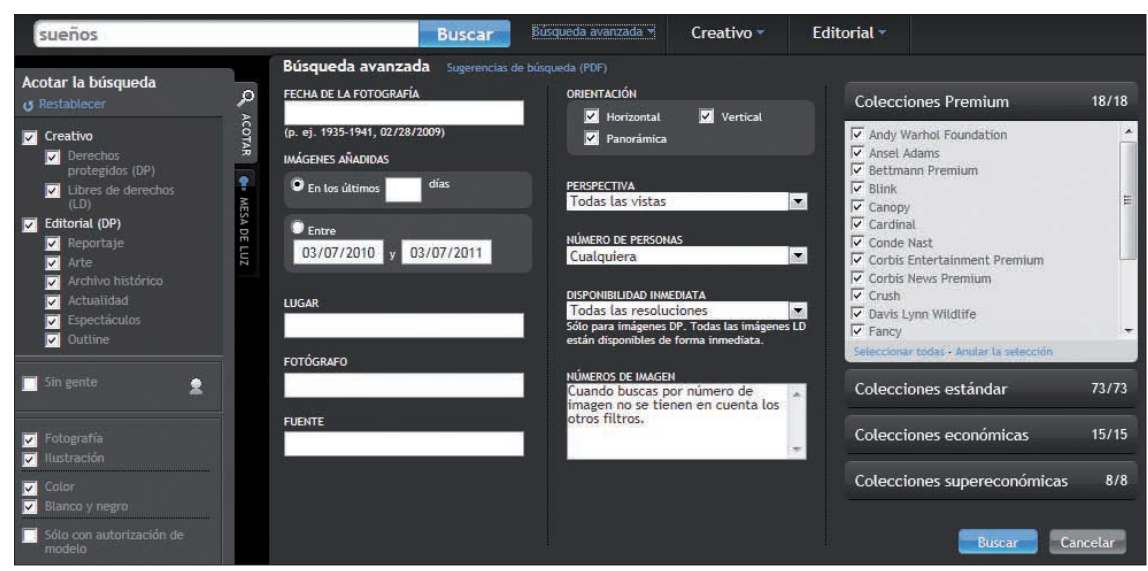

Figura 1: Vista parcial de la búsqueda avanzada en el banco de imágenes Corbis ella aparezca un número de personas (una, dos, ninguna, muchas) o que tengan determinada connotación conceptual (cosa que es imposible que un buscador pueda inferir de un archivo binario, y que sólo se puede conseguir mediante uso de lenguajes documentales y asignación intelectual de descriptores), etc.

Los bancos de imágenes forman parte también de la denominada industria de la información electrónica, junto con las bases de datos científicas y académicas (aunque pertenecen a nichos muy distintos), ya que generan una actividad de negocio alrededor de: (1) proporcionar acceso a colecciones de imágenes de gran calidad; (2) servicios de búsqueda avanzados e información de valor añadido en forma de categorizaciones conceptuales sofisticadas y metadatos descriptivos (descripciones y palabras clave) de las fotografías que forman la colección y (3) estableciendo un marco legal y contractual claro entre el usuario, el uso de la imagen y el poseedor de los derechos de copia de la misma.

\section{La fotografía de stock}

Para comprender el lugar de los bancos de imagen en el ecosistema informativo es necesario recurrir a un conjunto de tres dicotomías, articuladas a través de otros tres ejes respectivos, a saber:

- Génesis: fotografía de encargo vs fotografía de stock.

- Segmentación de mercado: sector editorial vs sector creativo.

- Tipo de licencia: derechos reservados vs libre de derechos.

En relación con el primer eje, cabe recordar que una expresión típica (obviamente heredada de la expresión inglesa correspondiente) es "fotografía de stock". De hecho, en inglés, la expresión image bank sería poco inteligible o muy ambigua, mientras que stock image o todavía mejor, stock photography, lo dice todo. Y aquí tenemos la primera dicotomía. Se supone que un medio de comunicación puede "encargar" las fotografías que necesita a su fotógrafo o puede obtenerlas a través de un banco de imágenes, que al fin y al cabo consiste en un stock o almacén de fotografías, específicamente organizado para su reutilización.

Claro que a veces se trata de una falsa opción. Un ejemplo podría ser el siguiente: por alguna razón un medio de comunicación necesita imágenes representativas del centro urbano de ciudades europeas (imaginemos un reportaje especial sobre vida urbana). La primera opción sería, más o menos, comisionar a un fotógrafo a que durante varios días o semanas se desplace por esas ciudades y haga las fotografías (rogando que haga siempre buen tiempo). La segunda sería explorar un buen banco de imágenes y buscar un grupo razonable de fotografías de stock para ilustrar el reportaje.

Decíamos que a veces es una falsa opción porque en este caso la primera solamente puede permitírsela un reducido grupo de empresas de comuni- 
cación, mientras que la segunda está al alcance de casi cualquier medio (sobre todo si cuentan con un buen experto en bancos de imágenes) dada la enorme diferencia de costes en tiempo y dinero que hay a favor de la segunda opción. Una variación sobre la anterior sería que el medio en cuestión busca imágenes representativas de cómo eran los centros urbanos en los años noventa. En este caso, salvo que el medio sepa cómo hacer viajar al fotógrafo al pasado, la única opción es el banco de imágenes.

La cuestión es, ¿de dónde proceden las imágenes de stock? Naturalmente, muchas imágenes de stock fueron en su momento imágenes de encargo, que luego pasaron a un banco de imágenes a través de alguna de las múltiples vías por las cuales las empresas que producen los bancos se hacen con su materia prima (contratos directos con fotógrafos, acuerdos comerciales con agencias, adquisición de archivos completos, etc.). Pero cada vez más, algunos bancos promueven la producción directa de fotografías para ser destinada a stock, y cada vez más fotógrafos dedican parte o la totalidad de su producción a la fotografía de stock.

\section{Segmentación}

Hay dos grandes segmentos de usuarios en el campo de la imagen, que suelen denominarse sector creativo y sector editorial respectivamente, y que vamos a considerar a continuación.

\subsection{Sector creativo}

Lo podemos caracterizar si consideramos que en el mismo encontramos, típicamente, a los siguientes tipos de profesionales o sectores:

- diseño gráfico;

- publicidad y relaciones públicas;

- departamentos de comunicación de empresas y organismos de la Administración;

- producción audiovisual de ficción.

A su vez, las imágenes de este sector presentan estas características generales:

- Suelen expresar conceptos e ideas, más que hechos concretos o puntuales.

- Por esta misma razón tienen capacidad para representar cosas relativamente abstractas, como éxito, trabajo en equipo, vida al aire libre, belleza, miedo, ciencia, etc. (el etcétera es virtualmente ilimitado).

- Tienen una excelente factura gráfica y una calidad técnica impecable.

- No están necesariamente ubicadas ni en un lugar ni en una fecha concreta. sector editorial.

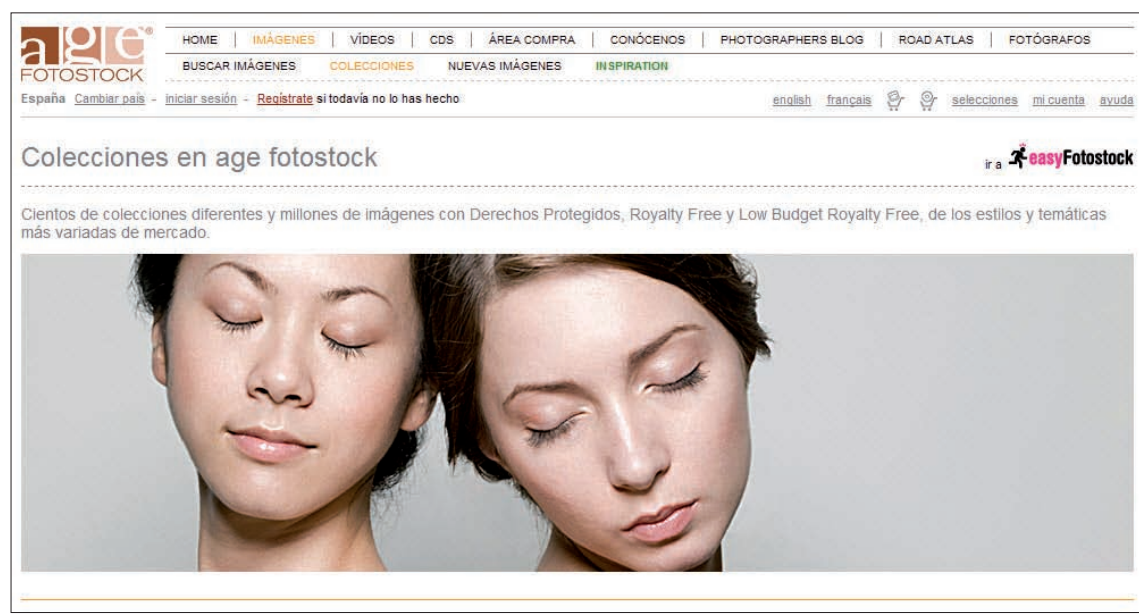

Figura 2: Las imágenes del sector creativo (en este caso de AGE Fotostock) pueden tener un gran poder de connotación y estar al mismo tiempo "deslocalizadas"

\subsection{Sector editorial}

Dentro del sector editorial encontramos los siguientes tipos característicos de profesionales o empresas:

- prensa, tanto diaria como no diaria;

- editoriales (libros);

- producción audiovisual de actualidad (informativos y documentales).

Por su parte, las características de la imagen editorial son las siguientes:

- Son relativas a hechos de actualidad o que lo fueron en su momento ( $p$. e. el intento de golpe de estado en España de 1981; triunfo de Fernando Alonso en la Fórmula 1 en 2007 , etc.). Para decirlo de otro modo, la imagen editorial es muy sinónima de actualidad, fotoperiodismo e historia.

- Por la razón anterior, están siempre vinculadas a un lugar y a una fecha (p. e. París, mayo del 68; manifestación estudiantes anti-Bolonia en Barcelona en febrero de 2009, etc.).

- No siempre son de calidad, aunque su valor testimonial puede obviar esta carencia en muchas ocasiones y pueden ser altamente exclusivas.

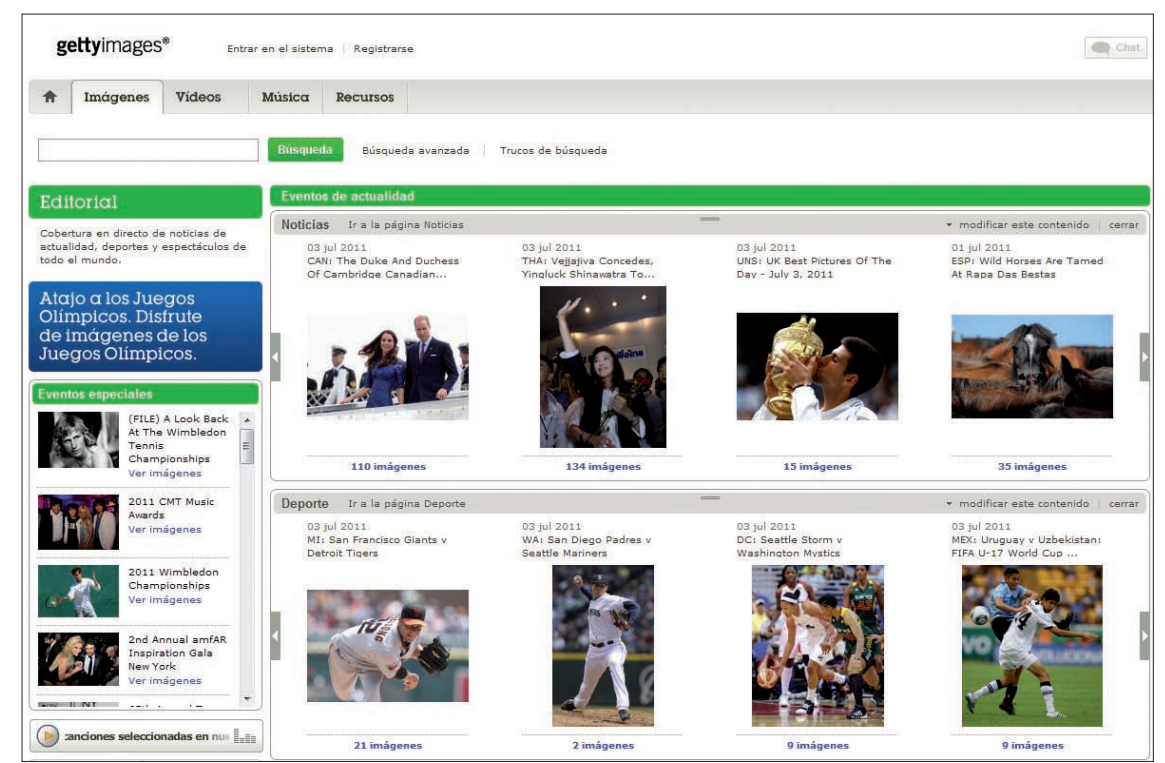

Figura 3: La página de eventos de actualidad de Getty Images es un buen ejemplo de fotografías del 
Por supuesto, hay siempre usos cruzados. Por ejemplo, un creativo publicitario puede necesitar imágenes del Mayo del 68 para un anuncio dirigido a personas de espíritu rebelde; el reportaje de un periódico diario sobre "hábitos de vida sana" puede necesitar imágenes con capacidad para transmitir estos conceptos y no tanto imágenes periodísticas, etc.

\section{Tipos de licencias}

A pesar de que haya que pagar una contraprestación para poder utilizar una fotografía en un banco de imágenes, esto no significa que sea de nuestra propiedad. Todo depende del tipo de licencia de uso a la que esté asociada la imagen en cuestión.

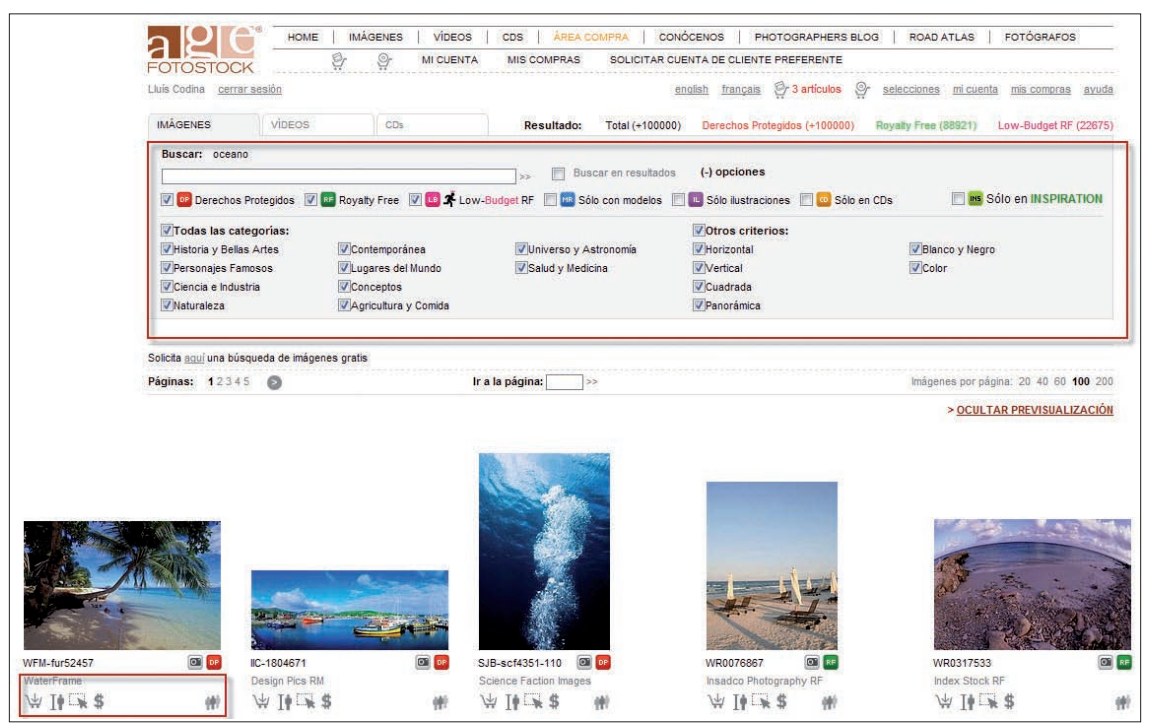

Figura 4: AGE Fotostock (página de resultados para la palabra clave "océano"). Puede observarse parte del sistema de categorización y de las opciones de búsqueda avanzada. Debajo de cada imagen están las opciones para ampliar información y calcular el precio en función de su uso o tipo de licencia.

En general, hay dos grandes tipos de licencia, que se suelen denominar "derechos protegidos" (rights managed) y "libre de derechos" (royalty free). Ninguno de los dos implica que la imagen sea gratuita: en ambos casos hay que pagar una determinada cantidad. Lo que cambia es la clase de uso que puede hacerse de la imagen por la que se ha hecho el desembolso.

En el caso de las imágenes del tipo derechos protegidos, lo que se obtiene es la exclusividad para el uso de la imagen en unas condiciones determinadas, en general durante un tiempo y en un ámbito geográfico concreto.

Por ejemplo, un medio de comunicación puede adquirir la licencia de uso de una imagen durante un mes como portada de una revista mensual de ámbito español. Este uso tendrá un precio, que puede ser de varias decenas o de varios cientos de euros, dependiendo de la exclusividad de la imagen. Fuera de ese uso, el medio no puede usar la imagen ni puede volver a publicarla, ni puede publicarla en paralelo en una revista del mismo grupo, etc.

En cambio, las imágenes adquiridas bajo una licencia royalty free (o libre de derechos) se pueden utilizar sin prácticamente restricciones ni límites temporales a casi todos los efectos prácticos. Incluso, en determinados, casos, las imágenes libres de derechos se pueden modificar y publicar como parte de una obra derivada. Deben leerse atentamente, sin embargo, las restricciones específicas de uso de cada imagen antes de adquirirlas porque hay casuística en este terreno. Determinadas imágenes libres de derechos pueden estar restringidas a ciertos países, o pueden tener un límite máximo de copias (que de todos modos suele ser muy alto), etc. En general, lo que no puede hacerse (como en la licencia anterior) es redistribuir la imagen a terceros y mucho menos a cambio de alguna prestación económica.

\section{Principales actores en nuestro entorno}

Una vez caracterizado el sector en virtud de los tres ejes anteriores, presentamos ahora los tres bancos de imágenes probablemente más significativos para las empresas de

comunicación de nuestro entorno: AGE Fotostock (España), Getty Images (EUA) y Corbis (EUA).

AGE Fotostock es una empresa española con delegaciones en Estados Unidos y clientes en todo el mundo. Es uno de los tres bancos de imágenes que presentamos aquí porque es, posiblemente, el más importante de nuestro país.

http://www.agefotostock.com

En cualquier búsqueda efectuada en $A G E$ obtenemos con casi total seguridad un gran número de propuestas donde elegir y unas fotografías de calidad impecable. Además, destaca la calidad de su sistema de categorización o indización de imágenes, basado en asignar a cada una un número muy amplio de palabras clave que refleja no solamente los elementos icónicos sino también los conceptuales denotados y connotados.

Por su parte, Getty Images está considerado el primer banco de imágenes del mundo, principalmente por la amplitud y la calidad de los fondos gráficos que posee, pero también por su sistema de categorización y su eficiente sistema de búsqueda. Como en otros bancos, sus colecciones de imágenes están distribuidas en dos amplias secciones cuyos nombres nos serán familiares: Creative y Editorial.

Debido a la riqueza y diversidad de sus fondos fotográficos tiene clientes y usuarios en prácticamente todo el mundo y seguramente no hay ninguna gran editorial, medio de comunicación o agencia de publicidad española que no haya utilizado alguna vez imágenes de este banco.

Corbis es una empresa de Bill Gates (el fundador de Microsoft). Por facturación es el segundo banco de imágenes del mundo. La riqueza y amplitud de sus fondos es comparable a la Getty.

http://www.corbisimages.com

\section{Alternativas: repositorios abiertos y licencias CC}

Además de las dos licencias comerciales mencionadas, hay un tercer tipo de licencias que son totalmente gratuitas. Las 


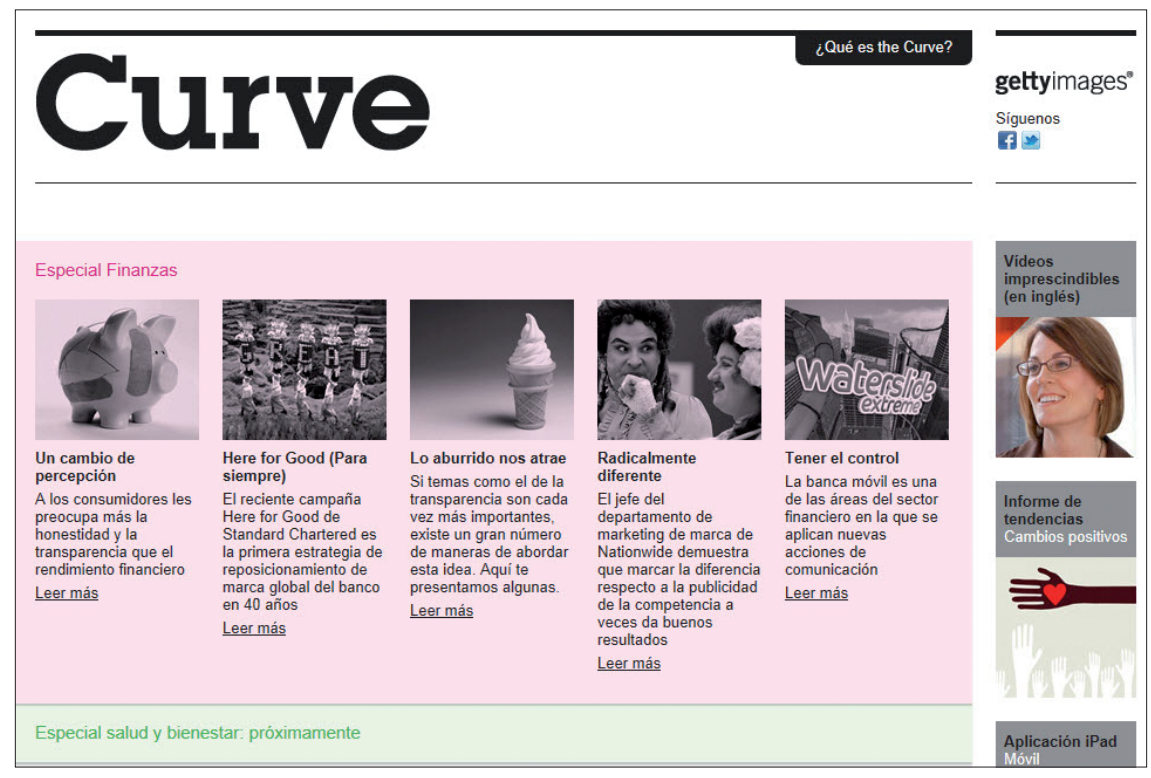

Figura 5: Getty es el principal banco de imágenes del mundo por su cuota de mercado y la riqueza de sus fondos. Aquí podemos ver la sección The Curve, con informes periódicos sobre el sector creativo.
Este tipo de licencias alternativas se encuentran en las imágenes disponibles fuera de los bancos comerciales (aunque algunos de estos bancos empiezan tímidas políticas de liberación de una pequeña parte de su colección).

Probablemente, en estos momentos, el repositorio con un mayor número de imágenes de dominio público sea el popular Flickr. Una parte de su colección está declarada de dominio público o bajo algún tipo de licencia CC. Pero la lista de repositorios con imágenes de dominio público no deja de crecer. Otros ejemplos serían Wikimedia Commons y Archive.org, con vídeos en este caso.

http://www.flickr.com

http://www.flickr.com/commons

http://commons.wikimedia.org

http://www.archive.org más habituales en el mundo de la fotografía suelen consistir en alguna variación de las denominadas Creative Commons (CC). Las imágenes con licencia de uso CC se pueden copiar y distribuir libremente sin contraprestación económica, pero siempre bajo algún tipo de restricciones.

La restricción genérica es la "atribución”. Atribución significa que quien copie o publique la imagen debe atribuirla a su autor, es decir, debe mencionar el nombre del fotógrafo.

Otras restricciones pueden referirse a que no se permita para usos comerciales (no para campañas de publicidad, por ejemplo) así como a la prohibición de crear obras derivadas (modificando el original).
La lectura estratégica de esto es la siguiente: hasta la existencia de esta clase de licencias, para las empresas de cualquier sector, no solamente el de la comunicación, la posibilidad de utilizar imágenes cedidas gratuita pero informalmente podía ser un regalo envenenado.

La aparición de las licencias CC puso orden y ha dado algo de seguridad jurídica a las empresas. Gracias a este tipo de licencias, si el autor de una obra realmente está dispuesto a cederla sin contrapartidas económicas, dispone ahora de un instrumento que le permite expresar esto con claridad y sin ambigüedades.

Como resultado el autor cede los derechos de reproducción de su obra exactamente en los térmi-

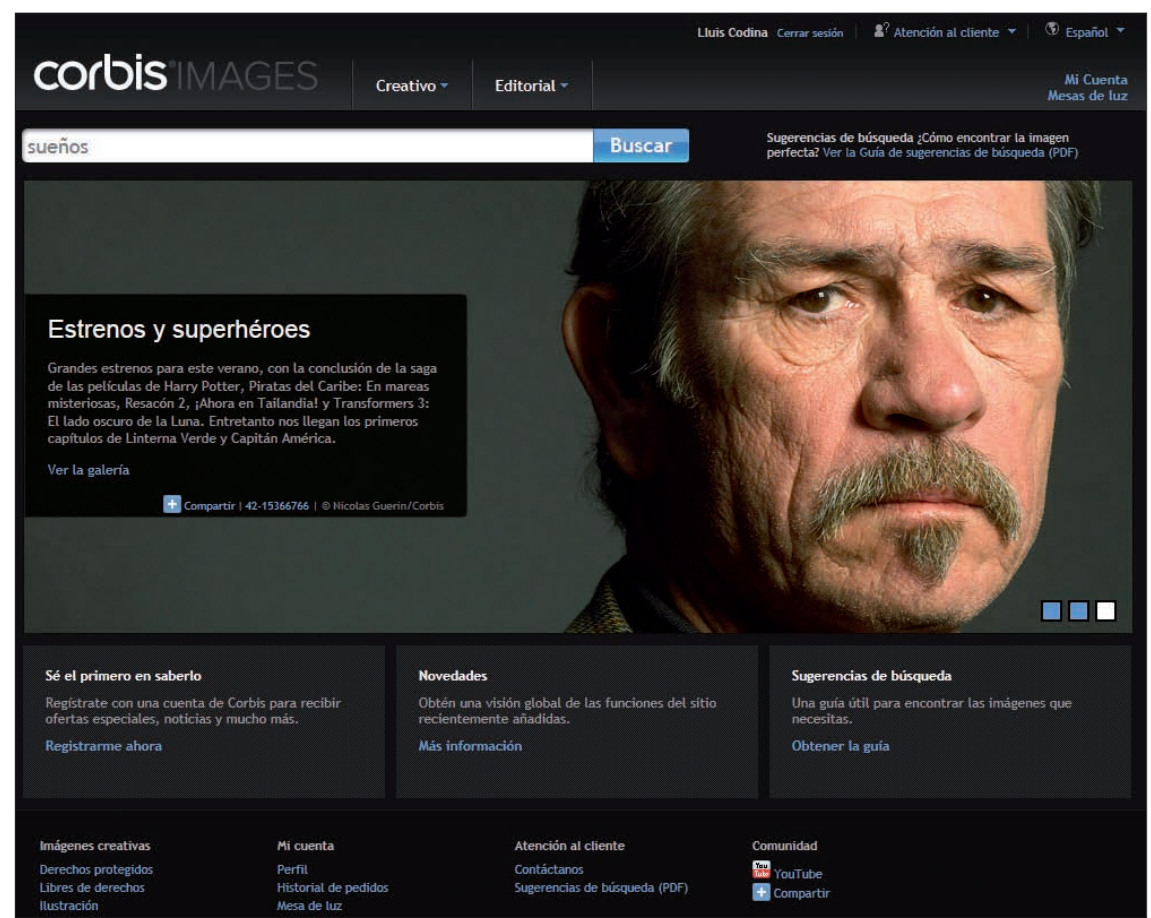

Figura 6. Página principal de Corbis. Junto con Getty, reúnen el mayor número de colecciones de fotoperiodismo y archivos históricos. Como puede verse, Corbis también cultiva la imagen de actualidad. nos que desea y no en otros, y quien se decida a utilizarla, sabe exactamente a qué atenerse y no necesita cruzar los dedos esperando que el autor no se arrepienta (por decir algo) de su decisión.

Aunque hay varias formas de buscar imágenes con licencia $\mathrm{CC}$, una de las más eficientes, como intenta mostrar la figura 7, es usando las opciones de búsqueda avanzada de Flickr, seleccionando la opción CC y, si es el caso, alguna de las dos sub opciones adicionales disponibles (con uso comercial y con obra derivada).

Otra posibilidad es utilizar el buscador de la fundación Creative Commons y activar la opción correspondiente en la búsqueda avanzada. Es posible también filtrar imágenes por el tipo de licencia en la búsqueda avanzada de Google.

http://www.flickr.com/search/advanced http://search.creativecommons.org 


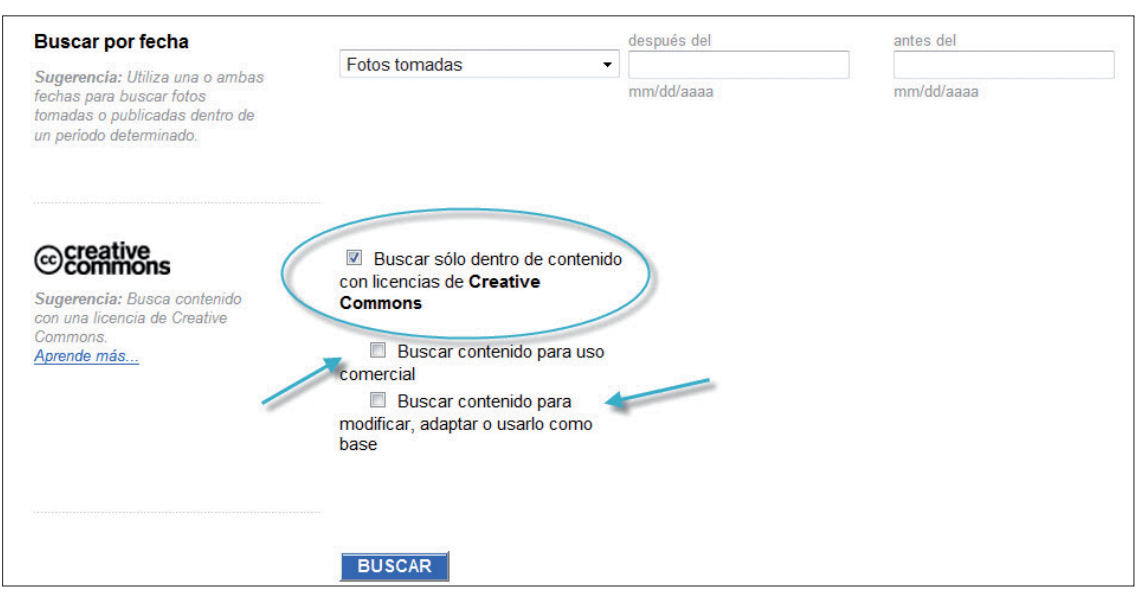

Figura 7: Parte de la búsqueda avanzada de Flickr con la opción que nos permite filtrar imágenes con licencia CC, http://www.flickr.com

\section{Conclusiones}

A partir de lo que hemos visto, ¿significa que es posible, e incluso deseable, prescindir de los bancos de imágenes comerciales a partir de ahora para toda clase de proyecto dada la existencia de las imágenes CC en Flickr o Google?

La respuesta, como puede suponerse, es que no. Hay varias razones para ello: legales, de eficiencia y de calidad. Si la empresa dispone de algún presupuesto para su proyecto o producto, siempre será más lógico usar un banco de imágenes comercial.

En primer lugar, seleccionar las imágenes más adecuadas para un proyecto en un banco como AGE Fotostock o Getty es un paseo, dadas las herramientas y facilidades de búsqueda que proporcionan. En comparación con las opciones de búsqueda de los bancos comerciales, al menos por el momento, las opciones de búsqueda de Flickr o de Google, son limitadísimas.

La necesidad de información que en un banco de imágenes se puede resolver en minutos, en Flickr o en Google puede requerir horas, para al final no encontrar ninguna imagen adecuada. Por tanto, lo que nos ahorramos en pagar la licencia de la imagen lo perdemos en tiempo, y esto en el

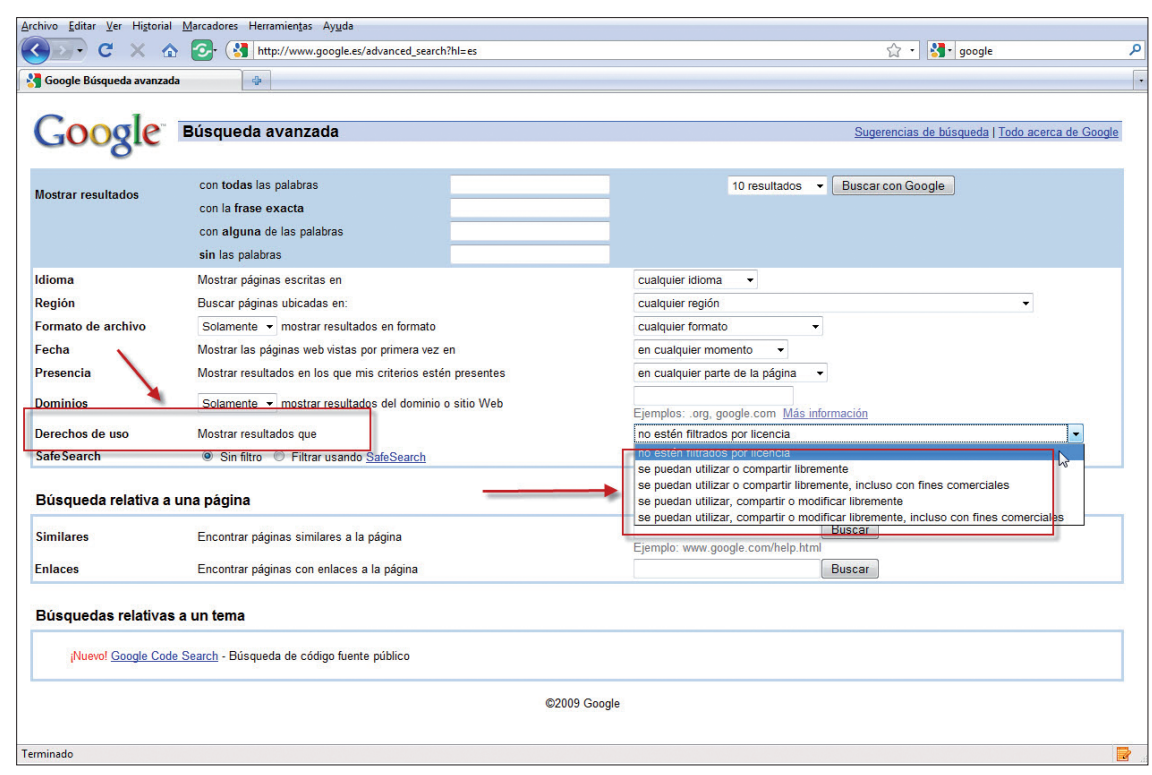

Figura 8: Opciones de filtrado CC en la búsqueda avanzada de Google. mejor de los casos. En el peor, si nuestra necesidad es muy específica y, especialmente, si es para usos creativos, puede que la búsqueda no arroje al final ningún resultado.

En segundo lugar, las licencias CC de ningún modo aseguran la exclusividad necesariamente asociada a algunos proyectos. Igual que nosotros podemos utilizarlas, cualquiera puede hacerlo. Por ejemplo, la revista (o la empresa) de la competencia.

En tercer lugar, aunque las licencias CC resuelven el problema de los derechos de propiedad intelectual no resuelven los derechos del modelo si en la fotografía aparecen personas, marcas comerciales, edificios singulares, etc. En el caso de las imágenes para el sector creativo ese puede ser un problema insalvable. La imagen para uso editorial dispone de una especie de "dispensa", de facto, para lo que atañe al permiso del modelo: si necesitamos ilustrar una manifestación en la que hubo una violencia, no esperaremos nunca a que el manifestante corriendo con el policía detrás se detenga a firmar un permiso al fotógrafo. Pero esa "dispensa" se esfuma en los usos del sector creativo.

En cuarto lugar, pese a la relativa garantía de la licencia CC, al no existir una relación contractual explícita con el autor de la fotografía (o con el propietario de los derechos) siempre habrá una relativa inseguridad para la empresa que utilice imágenes $\mathrm{CC}$, en particular si son utilizadas en un contexto que se preste a la controversia, como es típicamente, en el sector creativo, donde es casi obligatorio disponer del permiso del modelo si se quieren evitar conflictos que pueden obligar a indemnizar o retirar la campaña (o ambas cosas).

Por lo tanto, la decisión sobre qué medios utilizar, bancos de imágenes comerciales o repositorios CC, en ocasiones puede consistir en una cuestión de oportunidad. Si el proyecto carece de presupuesto, típicamente cuando es para proyectos no comerciales (imaginemos la campaña de una ONG a favor de los derechos humanos, o un proyecto de sensibilización hacia el medio ambiente de un departamento de la Administración, etc.), siempre será mejor usar imágenes CC que no usar ninguna en absoluto (por falta de presupuesto).

Por tanto, existe un continuo donde, en un extremo, tenemos los proyectos sin ánimo de lucro que claramente pueden beneficiarse de la nueva y generosa oferta de los repositorios de imágenes de dominio público o con licencias tipo CC, proyectos que en otro momento se hubieran quedado $\sin$ la posibilidad de utilizar imágenes; y en el otro extremo pro- 


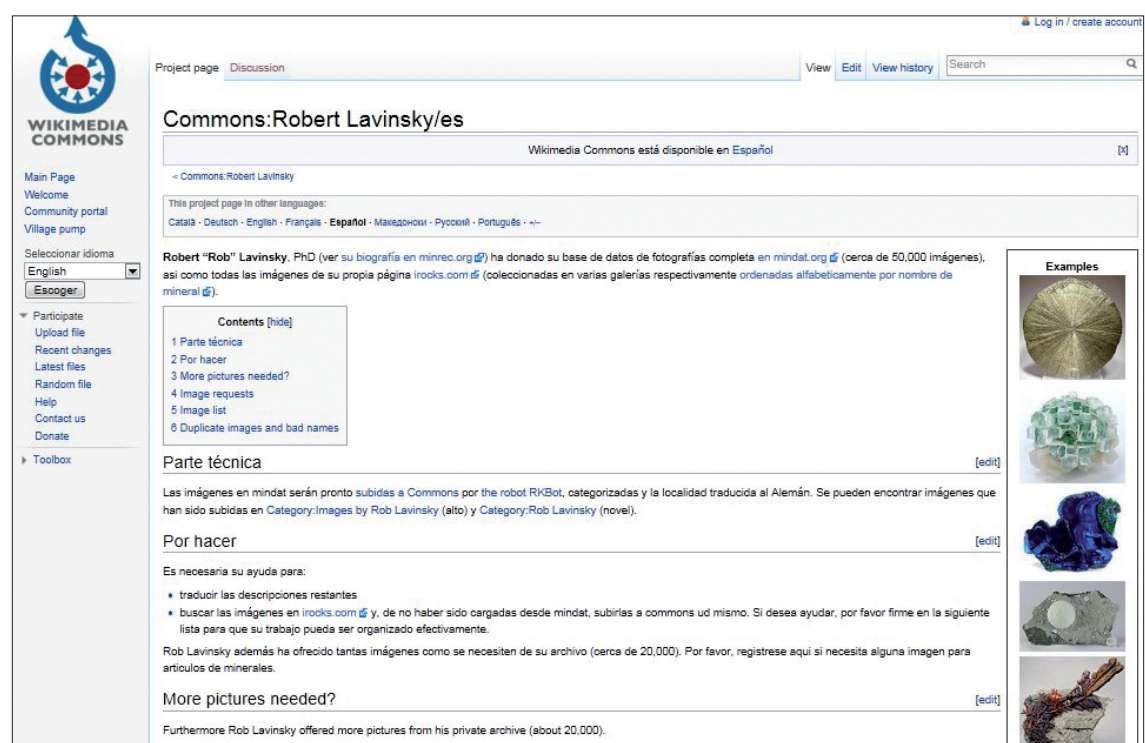

Figura 9: Colección Robert Lavinsky.

yectos comerciales donde parece difícil justificar que sus responsables -que ponen en juego los intereses o la cuota de mercado de la empresa, o el prestigio de una publicación- renuncien a los bancos comerciales con todas sus ventajas, servicios de valor añadido y seguridad jurídica que aportan.

\section{Nota}

Este trabajo forma parte del proyecto Evolución de los cibermedios españoles en el marco de la convergencia. Análisis del mensaje, CSO2009-13713-C05-04, del Ministerio de Ciencia e Innovación (Micinn).

\section{Bibliografía}

Abadal, Ernest; Guallar, Javier. Prensa digital y bibliotecas. Gijón: Trea, 2010.

Codina, Lluís. "Recursos multimedia para la comunicación audiovisual". Seminario DigiDoc, Barcelona, UPF, 2011.

http://www.Iluiscodina.com/Recur sosMultimediaProfesionalesV2011. $p d f$

Codina, Lluís. Directorio y diagrama interactivo sobre documentación audiovisual y bancos de imágenes, 2011. http://bit.ly/docaudio

Foust, James C. Online journalism: Principles and practices of news for the web, $2^{\text {nd }}$ ed. Scottsdale: Holcomb Hathaway, 2009.

Giménez-Toledo, Elea. Manual de documentación para comunicadores. Pamplona: Eunsa, 2004.

Muñoz-Castaño, Jesús E. "Bancos de imágenes: evaluación y análisis de los mecanismos de recuperación de imágenes". El profesional de la información, 2001, v. 10, n. 3, pp. 4-18.

Rubio-Lacoba, María. "Nuevos tiempos para la documentación informativa en el periodismo digital: Viejas y nuevas funciones del servicio de documentación digital". Comunicación y sociedad v. 18, n. 1, pp. 153-168.

Stock photography. Wikipedia.

http://en.wikipedia.org/wiki/Stock_photography

\section{EPI $n^{\circ} 1$ en el ranking In-Recs Y el Anuario ThinkEPI se estrena con la $7^{\mathrm{a}}$ posición}
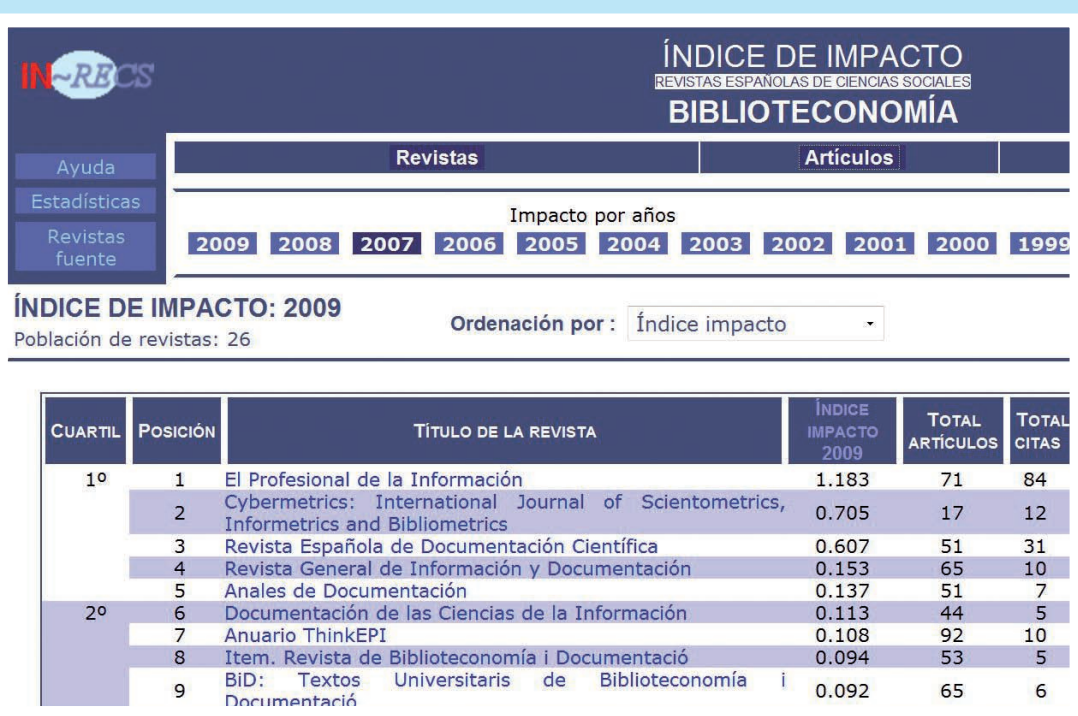

Según el Índice de Revistas Españolas de Ciencias Sociales (In-Recs), elaborado por el Grupo EC3 (Evaluación de la Ciencia y de la Comunicación Científica) de la Universidad de Granada: http://ec3.ugr.es/in-recs/ii/ Biblioteconomia-fecha-2009.htm la revista El profesional de la información ha conseguido situarse en primer lugar, de entre 26 revistas españolas de biblioteconomía y documentación. 